\title{
Revista Ciência \& Saúde: avanços e perspectivas
}

Os anos de 2012 e 2013 marcam, respectivamente, a consolidação da Revista Ciência \& Saúde no cenário nacional e a implementação de mudanças importantes visando a busca de uma maior abrangência e diversificação de indexações.

Em 2012, a Revista recebeu as suas primeiras classificações através do Sistema Qualis da CAPES, sendo avaliada por duas áreas distintas e obtendo classificação A2 na área do Serviço Social e B5 na área da Medicina II. Este primeiro reconhecimento confirma a qualidade do trabalho realizado nos últimos anos e motiva toda a equipe editorial na busca de um constante aperfeiçoamento. Além disso, 2012 marcou o ano de uma reformulação na estrutura de gerenciamento do processo editorial, com a inclusão de dois Editores Associados, a Prof ${ }^{\mathrm{a}}$. $\mathrm{Dr}^{\mathrm{a}}$. Alessandra Campani Pizzato (Nutricionista) e a Prof $^{\mathrm{a}}$. Dr ${ }^{\mathrm{a}}$. Ana Elizabeth Prado Lima Figueiredo (Enfermeira). Esta incorporação possibilitou não só uma maior agilidade no processo de avaliação dos manuscritos, diminuindo o tempo entre submissão e publicação, mas também um refinamento do processo de revisão, marcando a característica interdisciplinar do periódico. No ano de 2012, foram submetidos, aproximadamente, 97 artigos para a Revista, sendo 18 publicados, dos quais 14 são artigos originais. Assim, de uma maneira geral, a Revista espera um aumento significativo do número anual de manuscritos publicados e também da qualidade dos relatos através de um processo editorial mais eficiente.

Neste sentido, a partir deste ano (2013), a Revista Ciência \& Saúde passará de uma periodicidade semestral para quadrimestral, publicando três edições por ano. Este avanço é fruto do aumento da produção científica no Brasil, gerando uma grande demanda de relatos de pesquisa na área da saúde, e do aprimoramento e evolução dos processos editoriais em nosso periódico. Aos poucos, a Revista Ciência \& Saúde vai avançando, conquistando o seu espaço e reconhecimento, e buscando contribuir com a saúde e a ciência através de publicações de qualidade e relevância.

Por fim, é preciso agradecer aos leitores e pesquisadores que confiaram em nosso periódico através da submissão de seus trabalhos, à Administração Superior de nossa Universidade, à Divisão de Periódicos da PUCRS e aos membros do Conselho Editorial e Científico da nossa Revista.

Um excelente ano a todos!

Prof. Dr. Márcio Vinícius Fagundes Donadio, Editor-Chefe Revista Ciência \& Saúde 